\title{
Rôle des protéines Crumbs dans le contrôle de la morphogenèse des cellules épithéliales et des photorécepteurs
}

Céline Lemmers, Emmanuelle Médina, Lydie Lane-Guermonprez, Jean-Pierre Arsanto, André Le Bivic

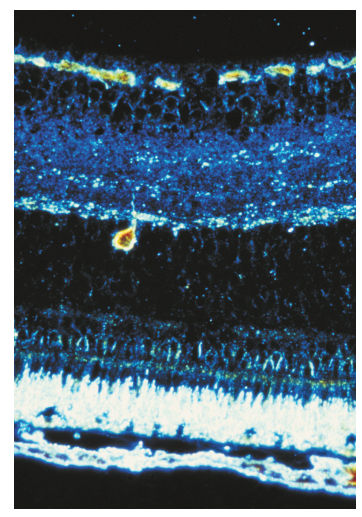

dégénérescence de la
C. Lemmers, $\varepsilon$. Médina, L. LaneGuermonprez, J.P. Arsanto, A. Le Bivic : UMR 6156, Laboratoire de neurogenèse et morphogenèse au cours du développement et chez l'adulte (NMDA), IBDM, Campus de Luminy, Case 907. 13288 Marseille Cedex 09. France.

lebivic@ibdm.univ-mrs.fr encore inexistante pour ces dégénérescences rétiniennes humaines. <

Les rétinites pigmentaires (RP) sont caractérisées par une perte de vision périphérique et bilatérale et une perte de vision nocturne (nyctalopie) (pour revue, voir [1]). Les RP peuvent être classées selon la fonction des produits des gènes soumis à mutation, regroupés dans quatre catégories principales: protéines de la cascade de transmission de l'influx lumineux, protéines de structure des photorécepteurs, protéines du métabolisme des photorécepteurs et des cellules épithéliales pigmentées, et facteurs de transcription. Le développement de la rétine est résumé dans la Figure 1A. Au cours de la différenciation et de la maturation de la rétine neurale, les couches impliquées dans le fonctionnement de la transmission du signal lumineux s'établissent (Figure 1B). Parmi ces structures, les plus touchées dans les RP sont les cellules épithéliales pigmentées $(R P \varepsilon)$ et les photorécepteurs (PR), ce qui provoque une rétine. Les cellules

$R P \varepsilon$, en contact étroit avec les segments externes des $P R$, sont impliquées dans leur phagocytose. Quant aux $P R$, ils établissent entre eux des jonctions ressemblant à des jonctions adhérentes, qui forment la membrane limitante externe et sont essentielles pour la cohésion de cette couche [2].

Cette revue traite $d u$ rôle $d u$ gène $C R B 1$, récemment impliqué dans un groupe de RP, les RP12, et dans certaines formes d'une autre dystrophie rétinienne, l'amaurose congénitale de Leber (LCA) [3, 4]. Nous montrerons comment l'étude de la fonction de ce gène et de ses partenaires chez la drosophile peut aider à comprendre plus rapidement son rôle chez l'homme. Les RP12 sont une forme autosomique récessive, cliniquement distincte et sévère de RP; les individus atteints de cette forme ont une perte de vision nocturne dès l'enfance, avec une réduction progressive de leurs champs de vision. L'examen ophtalmologique de leur rétine montre une préservation typique des RPE au voisinage des artérioles rétiniennes, alors que ces cellules sont perdues dans le reste de la rétine. Cette dégénérescence des RPE entraîne une dégradation de la macula et une 
atteinte sévère des capacités visuelles avant l'âge de 20 ans. L'amaurose congénitale de Leber est quant à elle considérée comme la forme la plus précoce et la plus sévère des dystrophies rétiniennes, car elle entraîne de graves pertes de vision, parfois même la cécité dès les premiers mois de vie. Quatre gènes sont impliqués dans environ $20 \%$ des cas de LCA, et $C R B I$ a été très récemment désigné comme étant un nouveau gène candidat dans certaines formes de LCA non liées aux 4 gènes déjà identifiés.

\section{CRB1 et gènes apparentés}

Ce gène a été isolé en 1999 à partir d'une banque enrichie en ADNc spécifiquement exprimés dans les cellules épithéliales pigmentées et la rétine. Un de ces ADNc correspondait à un gène localisé dans une région du génome humain correspondant au locus des RP12. Le gène ainsi identifié code pour une protéine de grande taille, Crumbs 1 (CRBl), qui présente plusieurs isoformes, dont une potentiellement secrétée (forme I) et une transmembranaire (forme II) [5]. Le domaine extracellulaire de CRBI contient 19 domaines apparentés au facteur de croissance de l'épiderme (EGF, epidermal growth factor) et 3 domaines apparentés au domaine $G$ de la laminine A. L'expression tissulaire de CRBI a été détectée dans l'œil et dans le cerveau, chez l'adulte, sans que les mécanismes qui régulent cette expression soient connus $[3,6]$. Dans la rétine, l'expression du messager de CRBI est restreinte aux photorécepteurs et aux neurones bipolaires tandis que, dans le reste de l'œil, seules les cellules de l'iris l'expriment.

Trois gènes apparentés sont maintenant répertoriés chez les mammifères (Figure $2 A)$ : la protéine CRB2 ressemble fortement à CRB1, tandis que CRB3 se distingue par un domaine extracellulaire très court. Toutes les protéines Crumbs identifiées ont un domaine cytoplasmique extrêmement bien conservé du ver à l'homme, ce qui prouve l'importance de ce domaine dans la fonction de cette protéine (Figure 2B).

La plupart des informations concernant le rôle potentiel de Crumbs chez les mammifères provient des études réalisées sur la drosophile et sur CRB3 dans les cellules épithéliales en culture.

\section{CRB et drosophile}

Chez la drosophile, tout défaut dans l'organisation ou la cohésion des cellules épithéliales entraîne un phénotype visible sur la cuticule secrétée par les cellules de l'ectoderme. Le gène crumbs, appelé ainsi car la cuticule de

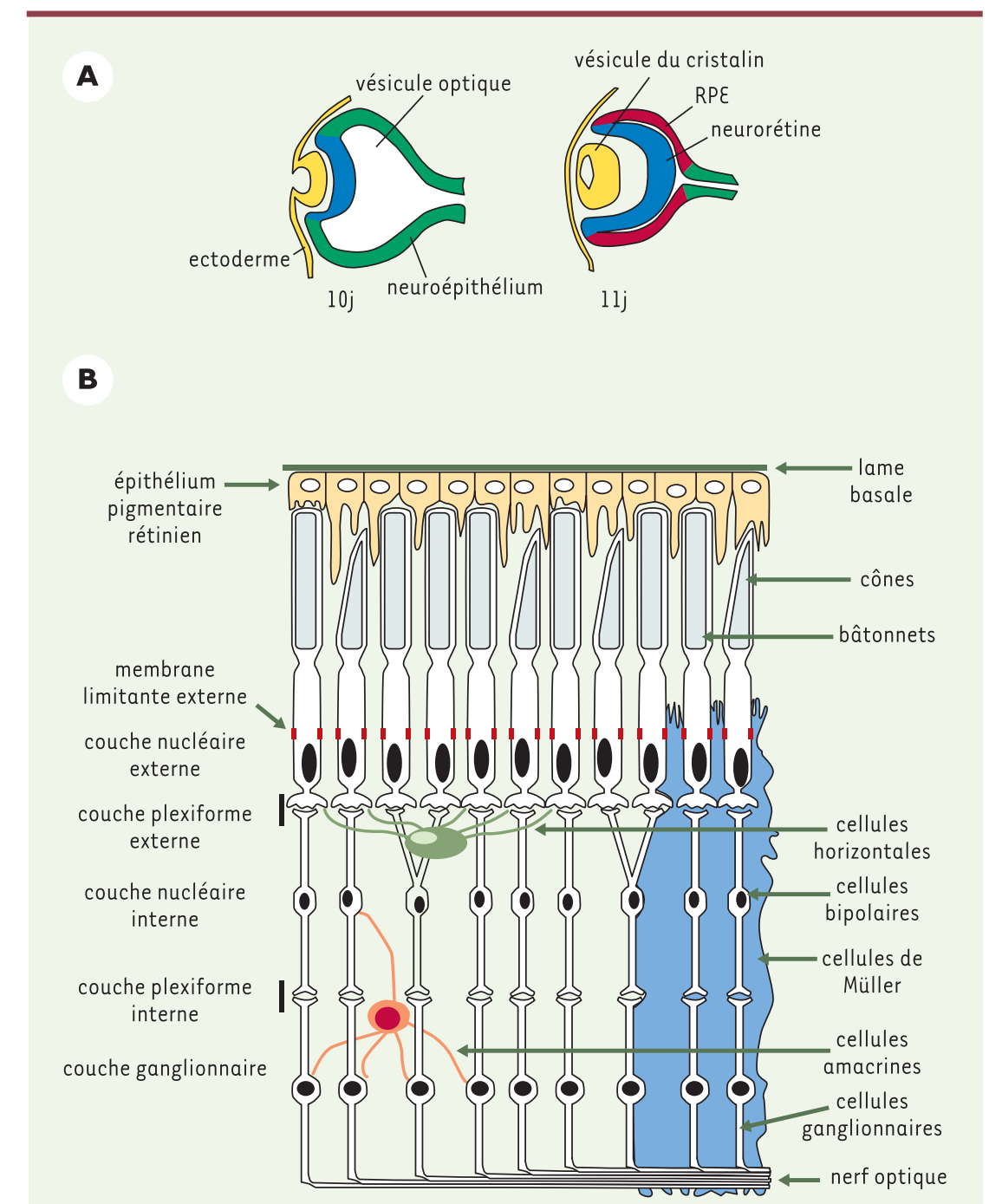

Figure 1. L'œil des mammifères. A. Formation de l'œil dans l'embryon de souris aux jours 10 et 11 de gestation. La vésicule optique formée par une évagination du neuroépithélium (en vert) s’invagine au contact de l'ectoderme (en jaune) pour se différencier en neurorétine (en bleu) et donner la future couche des cellules épithéliales pigmentées (retinal pigment epithelium, RPE) (en rouge). La neurorétine donnera naissance aux couches de photorécepteurs et de neurones schématisés en $\boldsymbol{B}$. L'ectoderme au contact du neuroépithélium forme la vésicule du cristallin par invagination et, en surface, la cornée et les paupières. $\boldsymbol{B}$. Coupe schématique de la rétine adulte de mammifères. La lumière traverse la neurorétine, excite les cônes et les bâtonnets, se transforme en influx nerveux, puis retraverse la rétine par l'intermédiaire des cellules bipolaires et des cellules ganglionnaires. Les cellules épithéliales pigmentées (en jaune) absorbent l'excédent de lumière, participent au métabolisme des produits de la cascade lumineuse et, par leurs membranes apicales, phagocytent les segments externes abîmés. 
l'embryon est littéralement «en miettes», code pour une protéine transmembranaire, Crumbs (Crb), contenant 30 domaines EGF et 4 domaines $G$ de la laminine $A$ [7]. La perte d'expression de Crumbs a pour conséquence un défaut de fusion des jonctions adhérentes au niveau de la zonula adherens (ZA), autour du pôle apical des cellules épithéliales de l'ectoderme [8], ce qui entraîne une perte de polarité et la mort des cellules épithéliales par apoptose $[7,9]$. Deux régions du domaine cytoplasmique de la protéine sont cruciales pour sa fonction dans les cellules des épithéliums primaires $[10,11]$; ces deux régions étant conservées de la drosophile à l'homme, il est probable que la protéine humaine est également impliquée dans le développement ou le maintien de la polarité cellulaire.

Les deux motifs de Crumbs impliqués dans l'organisation des zonula adherens et des épithéliums sont les quatre derniers acides aminés, $\varepsilon R L I$, et les acides aminés entourant la tyrosine (y) proche du domaine transmembranaire (Figure $2 B$ ). Le motif $\varepsilon R L I$ interagit avec la protéine cytoplasmique Stardust [12, 13], codée par le gène zygotique stardust ( $s d t)$ qui, lorsqu'il est muté, provoque l'apparition d'un phénotype très similaire à celui d'une déficience en Crb [14, 15]. Une autre protéine, D-PATJ (protein associated with tight junction), dont la fonction

A

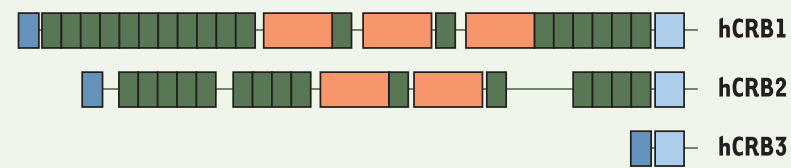

B

dCRB

hCRBI

hCRB2

hCRB3

CeCRBI

CeCRLI

DrCRB n'est pas encore connue, interagit avec Crb. Les protéines Sdt et D-PATJ sont des protéines d'échafaudage de complexes moléculaires sousmembranaires. Sdt est une MAGUK (membrane associated guanylate kinase), comme les protéines PSD95 (importante pour l'organisation des synapses neuronales) ou Z0-1 (essentielle pour l'organisation des jonctions serrées des cellules épithéliales) [16]: elle interagit avec Crb par son domaine PDZ (module d'interaction commun aux trois protéines PSD95, Discs large et Z0-1), tandis que D-PATJ, qui possède quatre domaines PDZ mais n'a pas de domaine catalytique [17], interagit avec Sdt par sa partie aminoterminale.

Crumbs interagit également avec le cytosquelette apical, nécessaire pour l'architecture et le maintien des zonula adherens [8]. Elle est en particulier requise pour l'organisation du cytosquelette contenant une spectrine apicale sous-membranaire [18], la $\beta_{\text {heavy }}$-spectrine, qui forme des tétramères avec l' $\alpha$-spectrine. Cette interaction pourrait être indirecte, via une interaction entre Crumbs et la D-moesine, un membre de la famille des protéines ERM (ezrine/radixine/moesine) [18] liant l'actine aux protéines membranaires et reconnaissant une séquence, présente dans le domaine cytoplasmique de Crumbs, indispensable à sa fonction [11]. Crumbs se situe donc au centre d'un réseau d'interactions entre des protéines d'assemblage de complexes, comme Sdt et D-PATJ, et des protéines directement liées au cytosquelette d'actine, ce qui permettrait de contrôler l'organisation de la zone marginale et la morphogenèse épithéliale [19, 20].

Un autre complexe, formé par les protéines Par3, Par6 et la PKCa (atypique), est essentiel à la morphogenèse épithéliale. Ce complexe a d'abord été identifié chez Caenorhabditis elegans, où il est crucial pour la première division asymétrique [21]. Il est conservé chez toutes les espèces animales, du ver à l'homme, et contrôle à la fois les divisions asymétriques et la polarité des cellules épithéliales (pour revue, voir [22]). Par3 contient trois domaines PDZ, tandis que Par6 contient un seul domaine PDZ [23], ainsi qu'un motif CRIB (Cdc42, Rac-interactive binding) interagissant avec certains membres de la famille des petites protéines $G$ telles que $\mathrm{Cdc} 42$, Rac et TC10. La liaison de Cdc42 à Par6 permet de découvrir le domaine aminoterminal de Par6 qui a la capacité d'activer la PKCa, ce qui entraîne la phosphorylation du domaine CR3 de Par3. La PKCa interagit donc, par son domaine kinase, avec Par3 et, par son domaine régulateur, avec Par6 [24]. La perte d'expression des gènes codant pour la PKCa ou pour Par6 entraîne chez la drosophile une perte de polarité de l'ectoderme et la formation de multicouches de cellules épithéliales, ce qui ressemble fortement au phénotype de surexpression de Crumbs, indiquant un lien entre les deux complexes [25, 26]. II a été montré récemment que la phosphatase $2 \mathrm{~A}$ (PP2A) est également associée à ce complexe et permet sa régulation [27]. Une coordination des complexes Crumbs et Par3/Par6/PKCa doit nécessairement exister dans les cellules épithéliales de l'embryon de drosophile 
afin de permettre la mise en place harmonieuse des différents éléments nécessaires à l'organisation des jonctions et de la polarité épithéliale.

\section{Les complexes importants pour la polarité épithéliale sont conservés chez les mammifères}

Ce qui distingue les cellules épithéliales des vertébrés de celles de la drosophile, par exemple, est leur capacité à former des jonctions serrées, assemblées en zonula occludens (20) et formées de protéines transmembranaires, l'occludine et les claudines [28].

$\rightarrow \mathrm{m} / \mathrm{s} \quad$ De nombreuses protéines associées à la face cyto2004, $n^{\circ}$ 5, plasmique de ces jonctions ont déjà fait l'objet de p.580 revues détaillées [29] $(\rightarrow)$. En revanche, le rôle des protéines des complexes Crumbs et Par3/6

dans la formation et le maintien des complexes jonctionnels chez les mammifères n'a été que récemment mis à jour.

Le complexe formé par les protéines Par3 - nommée ASIP (atypical PKC isotype-specific interacting protein) chez les mammifères, Par6 et la PKCa est localisé au niveau des jonctions serrées. II existe deux PKCa (z et I) ayant des rôles comparables, et au moins trois isoformes de Par6 ayant des distributions tissulaires différentes [24]. Des expériences de surexpression de la PKCa ou de Par6 dans des cellules épithéliales de la lignée MDCK (Madin-Darby canine kidney) montrent que la formation initiale des jonctions est ralentie, mais qu'une polarité normale est acquise par les cellules après l'établissement de ces jonctions $[24,30]$. L'activation de $C d c 42$, qui se lie à Par6, ou celle de la PP2A, qui déphosphoryle plusieurs protéines des jonctions telles que l'occludine et les claudines, provoque les mêmes effets, ce qui montre que le complexe Par3/6/PKCa est impliqué dans la mise en place et la maturation des jonctions serrées. La localisation de ce complexe cytosolique aux jonctions nécessite probablement une interaction avec des protéines membranaires, et il a été montré que JAM (junctional adhesion molecule), une protéine transmembranaire des jonctions serrées, est capable de se lier à Par3, ce qui pourrait permettre le recrutement du complexe à la membrane [31].

Les homologues des protéines du complexe Crumbs ont également été identifiés chez les mammifères et ont des organisations moléculaires conservées, dont les protéines PAT) (protein associated with tight junction) et Muppl (multi-PDZ domain protein 1), qui possèdent respectivement 8 et 13 domaines PDZ. PATJ a été localisé dans les jonctions serrées des cellules épithéliales et sa surexpression affecte l'accumulation de la protéine Z0-3 (zona occludens 3) dans cette structure [32]. PATJ interagit directement avec 20-3 par son $6^{\mathrm{e}}$ domaine PDZ et, avec la claudine 1 , par son $9^{e}$ domaine PDZ, ce qui renforce ses liens avec la jonction serrée [33]. PAT) se lie également à Palsl (protein associated with Lin-7, homologue de Sdt), une MAGUK localisée dans les jonctions serrées, et peut donc se lier potentiellement à d'autres protéines ayant un rôle à jouer dans l'organisation de la région apicale des jonctions [34]. La perte d'expression de Palsl perturbe l'établissement des jonctions serrées, indiquant que ce complexe de protéines est important pour ce processus [35]. CRB3 est exprimé par la majorité des épithéliums et sa surexpression entraîne aussi un défaut de formation des jonctions serrées $[36,37]$. CRB3 pourrait donc jouer, chez les mammifères, le rôle que joue Crumbs dans la morphogenèse et le maintien des jonctions dans l'ectoderme de la drosophile. Cette hypothèse devra être vérifiée par la production d'une souris déficiente en protéine CRB3.

\section{Mécanismes potentiels des maladies de la rétine dues à des mutations de CRBI}

Il est maintenant évident que, chez la drosophile, le complexe crumbs est indispensable pour la formation des ZA dans les cellules de l'ectoderme. Or, il existe chez les mammifères une structure jonctionnelle de type $Z A$, entre les photorécepteurs, et entre ces photorécepteurs et les cellules gliales de Müller. La protéine $C R B 1$, accumulée dans cette structure, pourrait jouer un rôle dans l'organisation de ces jonctions [38]. Cela est confirmé par l'observation que ces jonctions sont perturbées dans la lignée de souris rd8 qui possède une mutation dans le gène CRBI [39]. La morphogenèse de la rétine étant normale chez ces souris comme chez les patients, les protéines CRB2 ou CRB3 sont donc capables de compenser une perte de fonction de CRBI. Il est alors possible qu'une autre fonction de CRBI soit requise pour le fonctionnement correct de la rétine après la naissance. Cette fonction pourrait être portée par le domaine extracellulaire de $C R B 1$, car les mutations responsables des RP12 ou des LCA concernent ce domaine [3]. L'analyse de clones déficients en crb dans l'œil de drosophile a montré que le domaine cytoplasmique de Crumbs est essentiel pour la formation des ZA et de la tige des photorécepteurs, tandis que son domaine extracellulaire est important pour l'élongation des rhabdomères, l'équivalent du segment externe des photorécepteurs de mammifères $[38,40]$. Ce domaine extracellulaire de la protéine crumbs protège également la rétine de la dégénérescence progressive induite par la lumière [41], en favorisant la survie des photorécepteurs.

\section{Conclusions et perspectives}

D'autres protéines du complexe crumbs ou du complexe Par3/Par6/PKCa ont également montré leur importance dans la formation de l'œil chez le poisson zèbre (Danio rerio): c'est le cas de l'homologue de Palsl, étudié dans le mutant nagie oko [42], et de la PKCa I, dans le mutant heart and soul [43]. II est donc possible que d'autres membres de ces deux complexes puissent, chez l'homme, être responsables de RP. Des criblages systématiques de ces gènes devraient permettre de mieux apprécier leur contribution à ces pathologies rétiniennes fortement invalidantes. Une meilleure compréhension des mécanismes de dégé- 
nérescence rétinienne devrait quant à elle conduire à l'élaboration de nouvelles approches thérapeutiques [44]. $\diamond$

\section{SUMMARY}

The Crumbs protein and the control of epithelial cell and photoreceptor morphogenesis

Degeneration of retina can have many causes and among the genes involved, CRBI has been shown to be associated with Retinitis pigmentosa (RP) group 12 and Leber congenital amaurosis (LCA), two dramatic pathologies in young patients. CRBI belongs to a family of genes conserved from Caenorhabditis elegans to human. In Drosophila melanogaster, for example, crb is essential both for the formation of the adherens junctions in epithelial cells of ectodermal origin during gastrulation and for the morphogenesis of photoreceptors in the eye. Crumbs is a transmembrane protein with a short cytoplasmic domain that interacts with scaffold proteins, Stardust and Discs lost, and with the apical cytoskeleton made of moesin and $\beta_{\text {heavy }}$-spectrin. The extracellular domain of Crumbs is essential for its function in photoreceptors but so far there are no known proteins interacting with it. In human, there are three known crb homologues, CRB1, 2 and 3 , and CRBI is expressed in the retina and localizes to the adherens junctions of the rods. Based on the model drawn from Drosophila, CRBI could be involved in maintaining the morphology of rods to ensure a normal function of the retina. This is supported by the fact that the homologues of the known partners of Crumbs are also conserved in human and expressed in the retina. Understanding the precise molecular mechanism by which CRBl acts will help to find new therapies for patients suffering from RP12 and LCA. $\diamond$

\section{RÉFÉRENCES}

1. Pierce $\varepsilon A$. Pathways to photoreceptor cell death in inherited retinal degenerations. Bioessays 2001; 23: 605-18.

2. Williams DS, Arikawa K, Paallysaho T. Cytoskeletal components of the adherens junctions between the photoreceptors and the supportive Muller cells. J Comp Neurol 1990; 295: 155-64.

3. den Hollander Al, ten Brink JB, de Kok YJ, et al. Mutations in a human homologue of Drosophila crumbs cause retinitis pigmentosa (RP12). Nat Genet 1999; 23: 217-21.

4. den Hollander Al, Heckenlively JR, van den Born LI, et al. Leber congenital amaurosis and retinitis pigmentosa with Coats-like exudative vasculopathy are associated with mutations in the crumbs homologue 1 (CRB I) gene. Am J Hum Genet 2001; 69: 198-203.

5. den Hollander Al, Johnson K, de Kok YJ, et al. CRBI has a cytoplasmic domain that is functionally conserved between human and Drosophila. Hum Mol Genet 2001; 10 : 2767-73.

6. den Hollander Al, Ghiani M, de Kok YJ, et al. Isolation of Crbl, a mouse homologue of Drosophila crumbs, and analysis of its expression pattern in eye and brain. Mech Dev 2002; 110: 203-7.

7. Tepass U, Theres C, Knust $\varepsilon$. Crumbs encodes an $\varepsilon G F-$ like protein expressed on apical membranes of Drosophila epithelial cells and required for organization of epithelia. Cell 1990; 61: 787-99.

8. Tepass U, Tanentzapf G, Ward R, Fehon R. Epithelial cell polarity and cell junctions in Drosophila. Annu Rev Genet 2001; 35: 747-84.

9. Wodarz A, Grawe F, Knust $\varepsilon$. CRUMBS is involved in the control of apical protein targeting during Drosophila epithelial development. Mech Dev 1993; 44: 175-87.

10. Wodarz A, Hinz U, Engelbert M, Knust $\varepsilon$. Expression of crumbs confers apical character on plasma membrane domains of ectodermal epithelia of Drosophila. Cell $1995 ; 82: 67-76$.

11. Klebes $A$, Knust $\varepsilon$. A conserved motif in Crumbs is required for $\varepsilon$-cadherin localisation and zonula adherens formation in Drosophila. Curr Biol 2000; 10: 76-85.

12. Bachmann A, Schneider M, Theilenberg $\varepsilon$, et al. Drosophila Stardust is a partner of Crumbs in the control of epithelial cell polarity. Nature 2001; 414: 638-43.

13. Hong $\mathrm{Y}$, Stronach B, Perrimon N, et al. Drosophila Stardust interacts with Crumbs to control polarity of epithelia but not neuroblasts. Nature $2001 ; 414: 634-8$.

14. Tepass $U$, Knust $\varepsilon$. Crumbs and stardust act in a genetic pathway that controls the organization of epithelia in Drosophila melanogaster. Dev Biol 1993; 159: 311-26.

15. Grawe F, Wodarz A, Lee B, et al. The Drosophila genes crumbs and stardust are involved in the biogenesis of adherens junctions. Development 1996; 122: 951-9

16. Gonzalez-Mariscal L, Betanzos A, Avila-Flores A. MAGUK proteins: Structure and role in the tight junction. Semin Cell Dev Biol 2000; 11: 315-24.

17. Bhat MA, Izaddoost S, Lu Y, et al. Discs Lost, a novel multi-PDZ domain protein, establishes and maintains epithelial polarity. Cell 1999; $96: 833-45$

18. Medina $\varepsilon$, Williams J, Klipfell $\varepsilon$, et al. Crumbs interacts with moesin and $\beta$ heavy-spectrin in the apical membrane skeleton of Drosophila.J Cell Biol $2002 ; 158: 941-51$

19. Zarnescu DC, Thomas GH. Apical spectrin is essential for epithelial morphogenesis but not apicobasal polarity in Drosophila.J Cell Biol 1999; 146: 1075-86.

20. Polesello C, Delon I, Valenti P, et al. D-moesin controls actin-based cell shape and polarity during Drosophila melanogaster oogenesis. Nat Cell Biol 2002; 4: 782-9.

21. Tabuse Y, Izumi Y, Piano F, et al. Atypical protein kinase $C$ cooperates with PAR- 3 to establish embryonic polarity in Caenorrhabditis elegans. Development 1998; 125 : 3607-14.

22. Ohno S. Intercellular junctions and cellular polarity: The PAR-aPKC complex, a conserved core cassette playing fundamental roles in cell polarity. Curr Opin Cell Biol 2001; 13: 641-8.

23. Joberty G, Petersen C, Gao L, Macara IG. The cell-polarity protein Par6 links Par3 and atypical protein kinase $C$ to Cdc42. Nat Cell Biol 2000; 2: 531-9.

24. Gao L, Joberty G, Macara IG. Assembly of epithelial tight junctions is negatively regulated by Par6. Curr Biol 2002; 12: 221-5.

25. Wodarz A, Ramrath A, Grimm A, Knust $\varepsilon$. Drosophila atypical protein kinase C associates with Bazooka and controls polarity of epithelia and neuroblasts. I Cell Biol 2000; 150: 1361-74.

26. Petronczki M, Knoblich JA. DmPAR-6 directs epithelial polarity and asymmetric cell division of neuroblasts in Drosophila. Nat Cell Biol 2001; 3: 43-9.

27. Nunbhakdi-Craig V, Machleidt T, Ogris $\varepsilon$, et al. Protein phosphatase $2 A$ associates with and regulates atypical PKC and the epithelial tight junction complex. J Cell Biol 2002; 158: 967-78.

28. Tsukita S, Furuse M. Occludin and claudins in tight-junction strands: Leading or supporting players? Trends Cell Biol 1999; 9: 268-73.

29. Knust $\varepsilon$, Bossinger 0 . Composition and formation of intercellular junctions in epithelial cells. Science 2002; 298: 1955-9.

30. Suzuki A, Yamanaka T, Hirose T, et al. Atypical protein kinase $C$ is involved in the evolutionarily conserved par protein complex and plays a critical role in establishing epithelia-specific junctional structures.J Cell Biol 2001; 152: 1183-96.

31. Itoh M, Sasaki H, Furuse M, et al. Junctional adhesion molecule (JAM) binds to PAR3: A possible mechanism for the recruitment of PAR-3 to tight junctions. J Cell Biol 2001; 154: 491-7.

32. Lemmers C, Medina $\varepsilon$, Delgrossi MH, et al. hINADI/PATJ, a homolog of Discs lost, interacts with Crumbs and localizes to tight junctions in human epithelial cells. J Biol Chem 2002; 277: 25408-15.

33. Roh MH, Liu CJ, Laurinec S, Margolis B. The carboxyl terminus of zona occludens-3 binds and recruits a mammalian homologue of discs lost to tight junctions. J Biol Chem 2002; 277: 27501-9.

34. Roh MH, Makarova O, Liu CJ, et al. The Maguk protein, Pals l, functions as an adapter, linking mammalian homologues of Crumbs and Discs Lost. J Cell Biol 2002; 157: 161-72.

35. Straight SW, Shin K, Fogg VC, et al. Loss of PALSl expression leads to tight junction and polarity defects. Mol Biol Cell 2004; 15: 1981-90.

36. Roh MH, Fan S, Liu CJ, Margolis B. The Crumbs3-Palsl complex participates in the establishment of polarity in mammalian epithelial cells. J Cell Sci 2003; 116: 2895-906.

37. Lemmers C, Michel D, Lane-Guermonprez L, et al. CRB3 binds directly to Par6 and regulates the morphogenesis of the tight junctions in mammalian epithelial cells. Mol Biol Cell 2004; 15: 1324-33.

38. Pellikka M, Tanentzapf G, Pinto M, et al. Crumbs, the Drosophila homologue of human CRB1/RP12, is essential for photoreceptor morphogenesis. Nature 2002; 416: 143-9.

39. Mehalow AK, Kameya S, Smith RS, et al. CRBI is essential for external limiting membrane integrity and photoreceptor morphogenesis in the mammalian retina. Hum Mol Genet 2003; 12: 2179-89.

40. Izaddoost S, Nam SC, Bhat MA, et al. Drosophila Crumbs is a positional cue in photoreceptor adherens junctions and rhabdomeres. Nature 2002; 416: 178-83.

41. Johnson K, Grawe F, Grzeschik N, Knust $\varepsilon$. Drosophila crumbs is required to inhibit light-induced photoreceptor degeneration. Curr Biol 2002; 12: 1675-80.

42. Wei X, Malicki J. Nagie oko, encoding a MAGUK-family protein, is essential for cellular patterning of the retina. Nat Genet 2002; 31: 150-7.

43. Horne-Badovinac $S$, Lin D, Waldron S, et al. Positional cloning of heart and soul reveals multiple roles for PKC lambda in zebrafish organogenesis. Curr Biol 2001; $11: 1492-502$.

44. Bessant DA, Ali RR, Bhattacharya SS. Molecular genetics and prospects for therapy of the inherited retinal dystrophies. Curr Opin Genet Dev 2001; 11: 307-16.

TIRÉS À PART

A. Le Bivic 